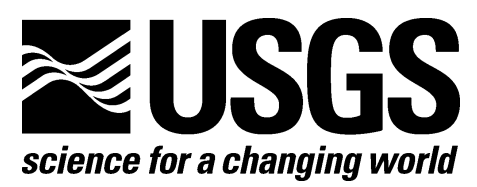

In Cooperation with the North Carolina Geological Survey

\title{
Hydrocarbon Source Rocks in the Deep River and Dan River Triassic Basins, North Carolina
}

By Jeffrey C. Reid and Robert C. Milici

Open-File Report 2008-1108

U.S. Department of the Interior U.S. Geological Survey 


\section{U.S. Department of the Interior DIRK KEMPTHORNE, Secretary}

\section{U.S. Geological Survey Mark D. Myers, Director}

U.S. Geological Survey, Reston, Virginia 2008

For product and ordering information:

World Wide Web: http://www.usgs.gov/pubprod

Telephone: 1-888-ASK-USGS

For more information on the USGS - the Federal source for science about the Earth, its natural and living resources, natural hazards, and the environment:

World Wide Web: http://www.usgs.gov

Telephone: 1-888-ASK-USGS

Suggested citation:

Reid, J.C., and Milici, R.C., 2008, Hydrocarbon source rocks in the Deep River and Dan River Triassic Basins, North Carolina: U.S. Geological Survey Open-File Report 2008-1108, 28p.

Any use of trade, product, or firm names is for descriptive purposes only and does not imply endorsement by the U.S. Government.

Although this report is in the public domain, permission must be secured from the individual copyright owners to reproduce any copyrighted material contained within this report. 


\section{Contents}

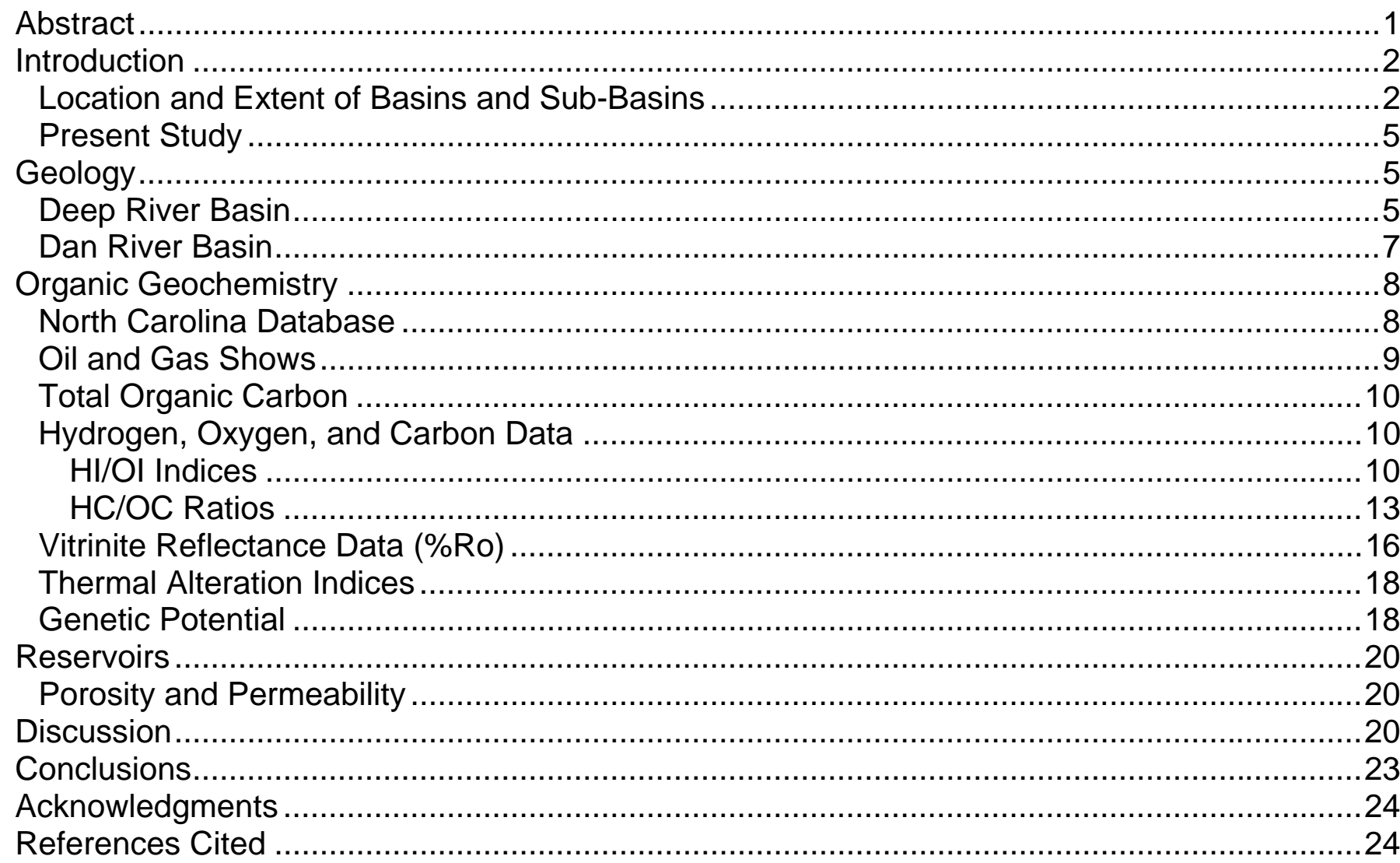

\section{Figures}

1a. Generalized geologic map of North Carolina and adjacent states, showing major geologic regions and locations of drill holes in Triassic basins (Geological regions from Schruben and others, 2006). See figure 1b for map numbers in center of Sanford sub-basin

1b. Generalized geologic map of Sanford sub-basin, showing location of drill holes

2. Generalized map of North Carolina, showing the major geologic regions and the locations of Triassic basins and sub-basins (North Carolina Geological Survey, 2006)

3. Stratigraphic nomenclature of the Deep River and Dan River Triassic basins, North Carolina (after Reinemund, 1955; Luttrell, 1989; North Carolina Geological Survey, 2006)

4. Distribution of TOC data from wells in the Dan River and Durham basins

5. Plot of hydrogen and oxygen indices from Rock-Eval pyrolysis in relation to primary kerogen type (shown by Roman numerals). Main evolutionary pathways are indicated by red arrows (Tissot and Welte, 1978) - Deep River basin (black) Dan River basin (red)

6. H/C and O/C ratios of kerogen types I - IV. Type I is floccules collalginite, or sapropelic; type II is liptinite, except alginite; type III is "low-gray" vitrinite, and type IV is fusinite and "high gray" material. Arrows show evolution paths of increasing maturity. O represents the formation of oxygenated products ( $\mathrm{CO} 2, \mathrm{H} 2 \mathrm{O}$, heavy heteroatomic molecules); Oil petroleum formation; Gas - gas formation (after Bostick,1979, who modified this diagram by Tissot and Espitalie,1975). Data (red circles) are from well CH-C-1-44, Cumnock Formation, Sanford sub-basin of the Deep River basin 
7. Plot of depth vs. \%Ro for selected wells in the Dan River and Deep River basins, showing the relationship of thermal maturity, measured as \%Ro, to depth. Hydrocarbon generation and preservation limits from Houseknecht and Spotl (1993)

8. Comparison of Tmax and Hydrogen Index of samples from wells in the Durham basin, Sanford sub-basin

9. Thermal maturation indices and zones of hydrocarbon generation and destruction (modified slightly from Dow and O'Conner, 1982)

\section{Tables}

1. Tabulation of drill holes in North Carolina Triassic basins

2. Triassic oil and gas shows reported from samples in the repository of the North Carolina Geological Survey. The rating indicates the relative quality of the show. Locations are shown on figure $1 b$

\section{Appendix A}

Appendix A: Organic geochemistry database of potential source rocks in Triassic strata, North Carolina Mesozoic basins 


\title{
Hydrocarbon Source Rocks in the Deep River and Dan River Triassic Basins, North Carolina
}

\author{
By Jeffrey C. Reid ${ }^{1}$ and Robert C. Milici ${ }^{2}$
}

\section{Abstract}

This report presents an interpretation of the hydrocarbon source rock potential of the Triassic sedimentary rocks of the Deep River and Dan River basins, North Carolina, based on previously unpublished organic geochemistry data. The organic geochemical data, 87 samples from 28 drill holes, are from the Sanford sub-basin (Cumnock Formation) of the Deep River basin, and from the Dan River basin (Cow Branch Formation). The available organic geochemical data are biased, however, because many of the samples collected for analyses by industry were from drill holes that contained intrusive diabase dikes, sills, and sheets of early Mesozoic age. These intrusive rocks heated and metamorphosed the surrounding sediments and organic matter in the black shale and coal bed source rocks and, thus, masked the source rock potential that they would have had in an unaltered state. In places, heat from the intrusives generated over-mature vitrinite reflectance (\%Ro) profiles and metamorphosed the coals to semi-anthracite, anthracite, and coke. The maximum burial depth of these coal beds is unknown, and depth of burial may also have contributed to elevated thermal maturation profiles.

The organic geochemistry data show that potential source rocks exist in the Sanford sub-basin and Dan River basin and that the sediments are gas prone rather than oil prone, although both types of hydrocarbons were generated. Total organic carbon (TOC) data for 56 of the samples are greater than the conservative 1.4\% TOC threshold necessary for hydrocarbon expulsion. Both the Cow Branch Formation (Dan River basin) and the Cumnock Formation (Deep River basin, Sanford sub-basin) contain potential source rocks for oil, but they are more likely to have yielded natural gas. The organic material in these formations was derived primarily from terrestrial Type III woody (coaly) material and secondarily from lacustrine Type I (algal) material. Both the thermal alteration index (TAI) and vitrinite reflectance data (\%Ro) indicate levels of thermal maturity suitable for generation of hydrocarbons.

The genetic potential of the source rocks in these Triassic basins is moderate to high and many source rock sections have at least some potential for hydrocarbon generation. Some data for the Cumnock Formation indicate a considerably higher source rock potential than the basin average, with S1 + S2 data in the mid-20 mg HC/g sample range, and some hydrocarbons have been generated. This implies that the genetic potential for all of these strata may have been higher prior to the igneous activity. However, the intergranular porosity and permeability of the Triassic strata are low, which makes fractured reservoirs more attractive as drilling targets.

In some places, gravity and magnetic surveys that are used to locate buried intrusive rock may identify local thermal sources that have facilitated gas generation. Alternatively, awareness of

\footnotetext{
${ }^{1}$ North Carolina Geological Survey

${ }^{2}$ U.S. Geological Survey
} 
the distribution of large intrusive igneous bodies at depth may direct exploration into other areas, where thermal maturation is less than the limits of hydrocarbon destruction. Areas prospective for natural gas also contain large surficial clay resources and any gas discovered could be used as fuel for local industries that produce clay products (principally brick), as well as fuel for other local industries.

\section{Introduction}

\section{Location and Extent of Basins}

The Deep River basin, named for the Deep River coal field, extends from the Sanford subbasin in Chatham, Lee, and Moore counties to the Durham sub-basin in Chatham, Wake, Orange, Durham, and Granville counties, North Carolina (figs. 1a,b; 2). The two sub-basins are separated by the Colon cross-structure in Lee County. The Colon cross structure, which contains many northwest-trending diabase dikes, is about 8 miles long and 5 miles wide. The Colon cross structure is a constriction in the Deep River basin that separates the Sanford sub-basin from the Durham subbasin and it apparently was caused by a faulted anticlinal structure (Reinemund, 1955; Randazzo and Copeland, 1976). The Sanford sub-basin is about 32 miles long and has a maximum width of 14 miles. The Durham sub-basin, north of the Colon cross structure, is about 52 miles long and has a maximum width of about 14 miles. The Deep River coal field is primarily in the central part of the Sanford sub-basin, generally to the north and west of the town of Sanford (fig. 2) (Reinemund, 1955; Toenges and others, 1952; Campbell and Kimball, 1923). Campbell and Kimball (1923) refer to the petroleum possibilities in the Deep River field, provide coal composition analyses, and suggest that the possibility of finding natural gas is greater than that of finding oil.

To the southwest, the Wadesboro sub-basin forms the third part of the Deep River basin. It extends through Montgomery, Richmond, and Anson counties for almost 45 miles, and is about 10 miles wide. It is separated from the Sanford sub-basin by about 15 miles of Coastal Plain deposits and by the Pekin cross structure (Randazzo and Copeland, 1976). The Pekin cross structure is similar to the Colon cross structure in that it is relatively narrow and contains many northwesttrending dikes. The exposed part of the structure is about 8 miles long and 5 miles wide, and it, too, may represent an anticlinal cross fold (Randazzo and Copeland, 1976).

The Dan River Basin in North Carolina, also known as the Danville Basin in Virginia (Meyertons, 1963; Luttrell, 1989; Robbins, 1982), is a half-graben that extends for 40 miles from north of Winston-Salem, through Stokes and Rockingham counties, North Carolina, into Virginia. The entire basin is about 105 miles long, and has a maximum width of about 6 miles (fig. 1a). 


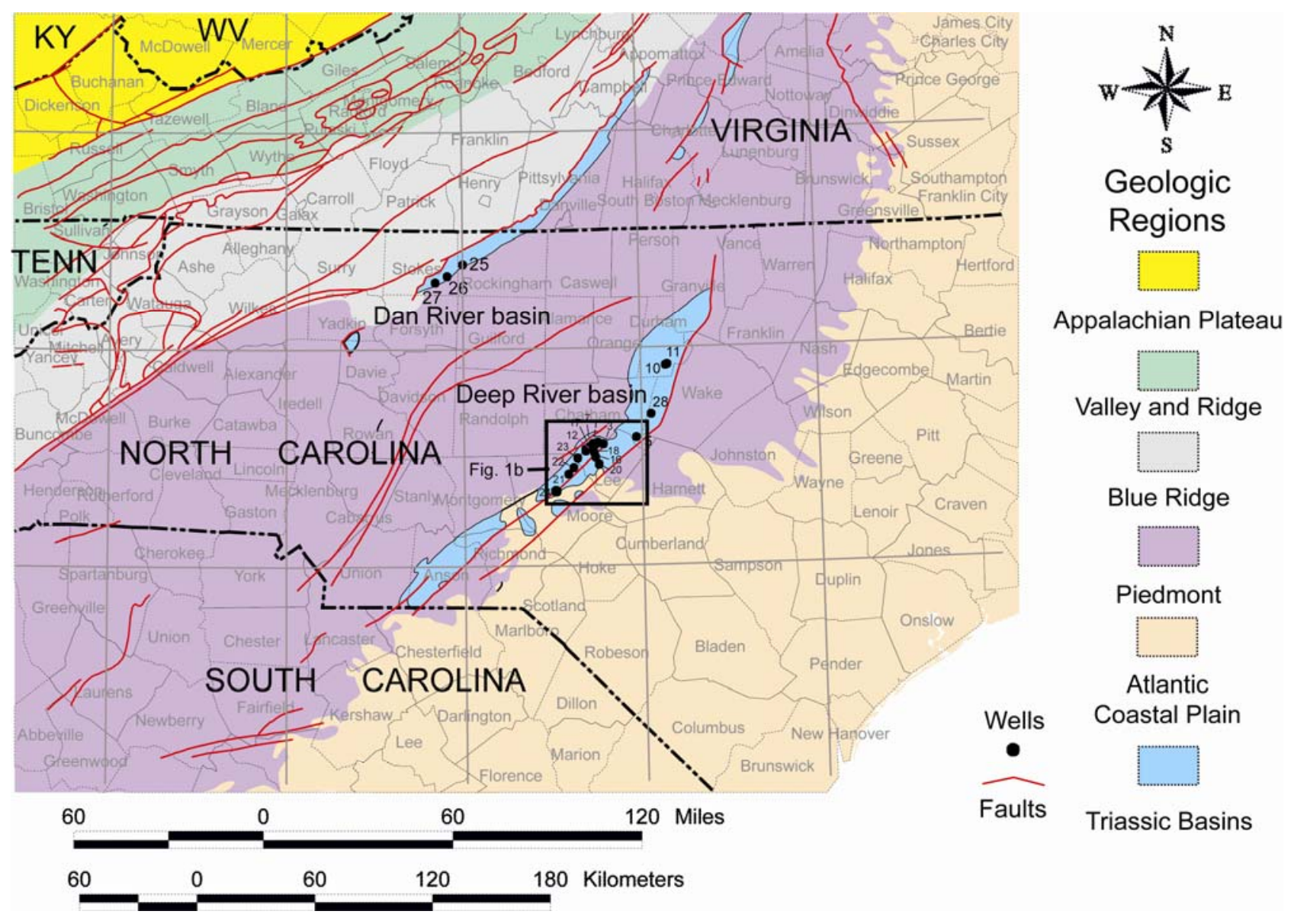

Figure 1a. Generalized geologic map of North Carolina and adjacent states, showing major geologic regions and locations of drill holes in Triassic basins (Geological regions from Schruben and others, 2006). See figure 1b for map numbers in center of Sanford sub-basin. 

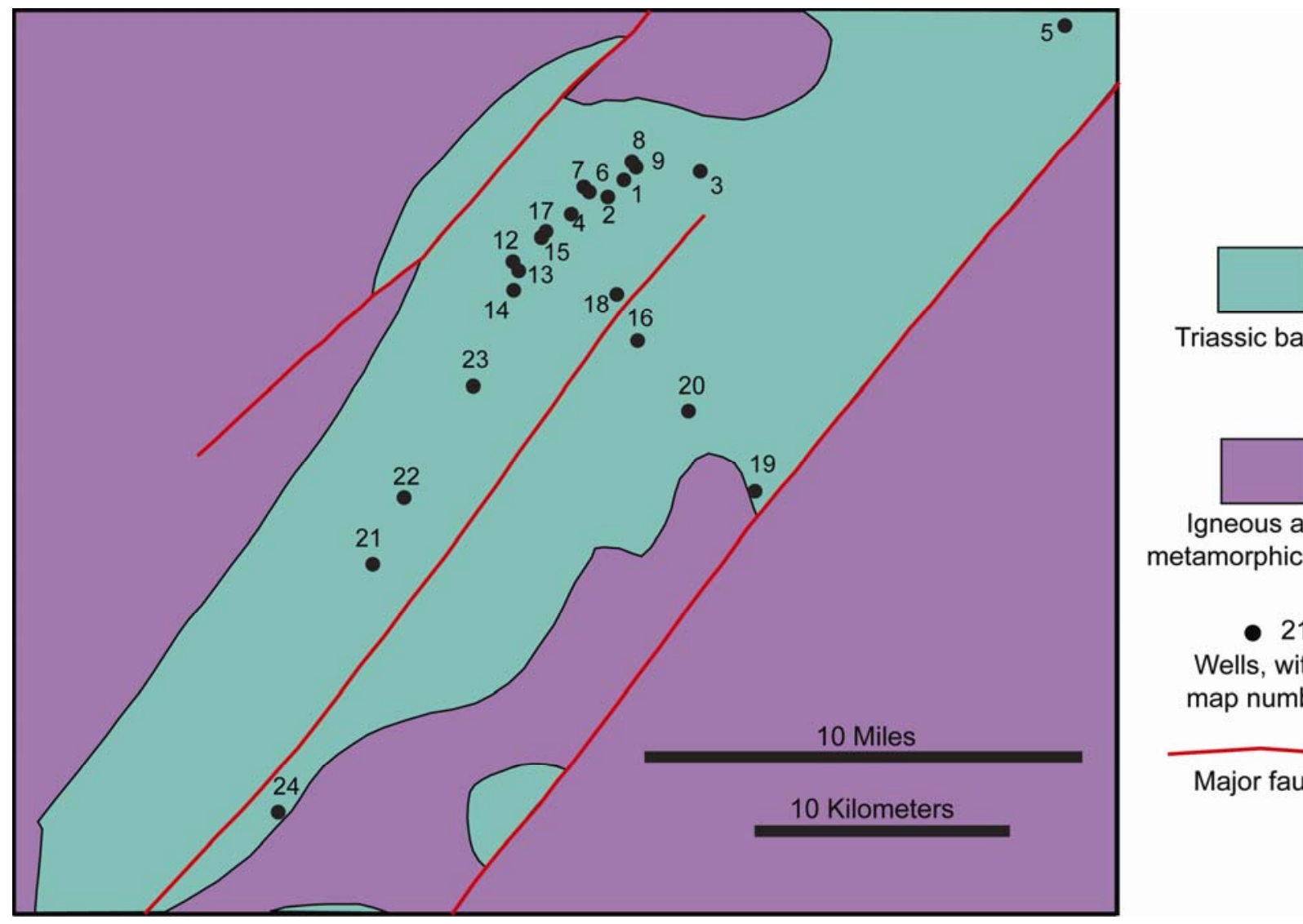

Triassic basins

Igneous and metamorphic rocks

- 21

Wells, with map number

Major faults

Figure 1b. Generalized geologic map of Sanford sub-basin, showing location of drill holes (Geology adapted from Schruben and others, 2006). 


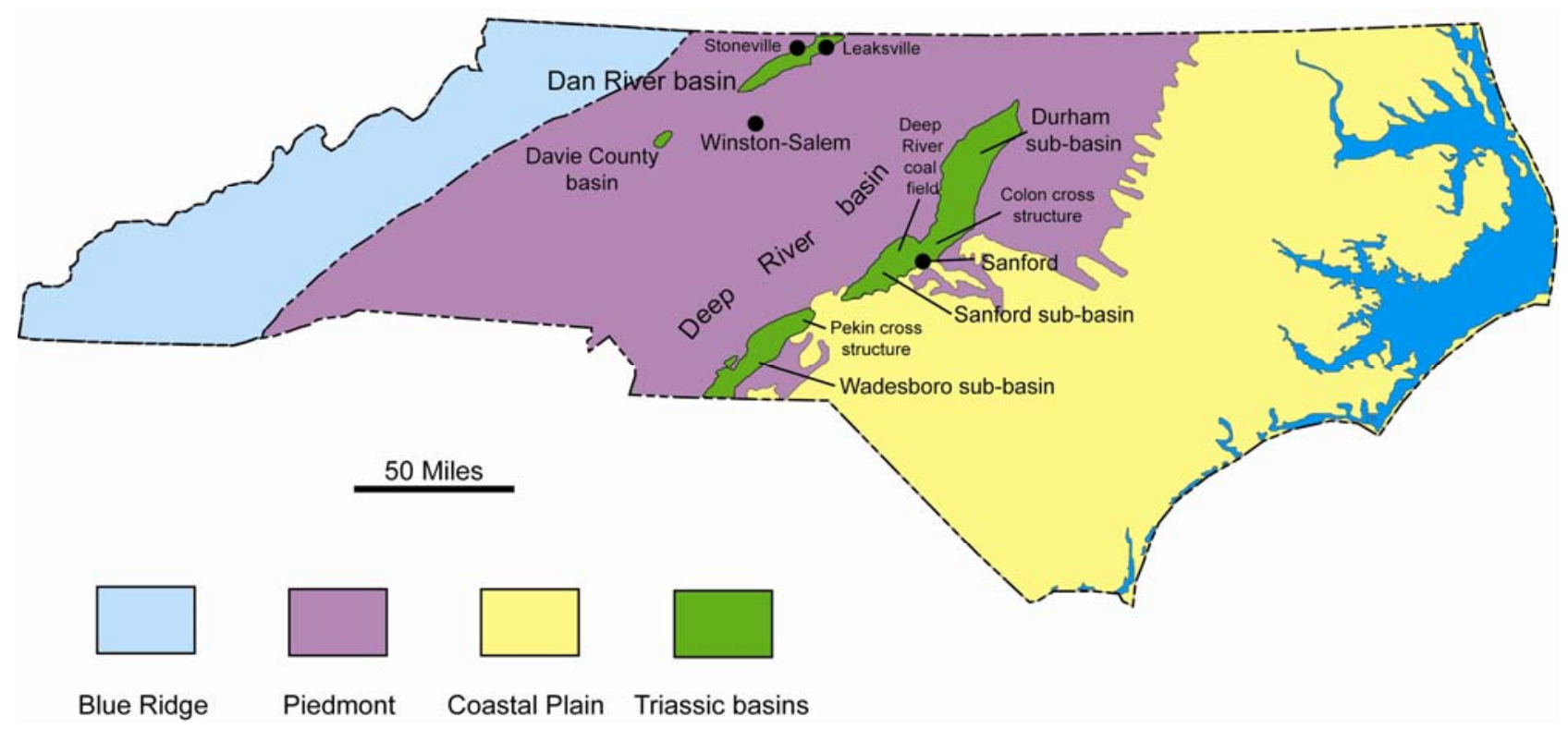

Figure 2. Generalized map of North Carolina, showing the major geologic regions and the locations of Triassic basins and sub-basins (North Carolina Geological Survey, 2006)

\section{Present Study}

This report describes the hydrocarbon source rock potential of coal beds and black shales within the Deep River and Dan River basins, North Carolina (figs. 1a,b and 2), based on previously unpublished organic geochemistry data obtained from core samples. In general, organic geochemical data and hydrocarbon source rock potential data are useful for the exploration of conventional natural gas accumulations and for continuous accumulations, such as shale gas and coal-bed methane. Hydrocarbon exploration in the Triassic rift basins of the eastern United States has been spasmodic because they consist largely of continental red beds and some are extensively faulted. However, renewed geological interest in these basins was shown in the late 1980's and early 1990's because of their potential for coalbed methane production and the recognition that they might contain lacustrine source rocks (Frolich and Robinson, 1988; Margolis and others, 1988; and Luttrell, 1989; Milici and others, 1991). In 1995, the U.S. Geological Survey assessed the technically recoverable undiscovered hydrocarbon potential of the eastern Triassic basins as containing an hypothetical potential of 348.2 billion cubic feet of gas, at the mean (Milici, 1995)

\section{Geology}

\section{Deep River Basin}

Stratigraphy:- The stratigraphic nomenclature presently used by the North Carolina Geological Survey for the Deep River Triassic basin is shown in figure 3. In general, the conglomerates, sandstones and mudstones of the basal Pekin Formation are overlain by the gray to black sandstones, mudstones, coal beds, and carbonaceous shales of the Cumnock Formation. These, in turn, are overlain by the conglomerates, fanglomerates, sandstones and mudstones of the 
Sanford Formation. All three formations are classified within the Chatham Group of the Newark Supergroup (Luttrell, 1989).

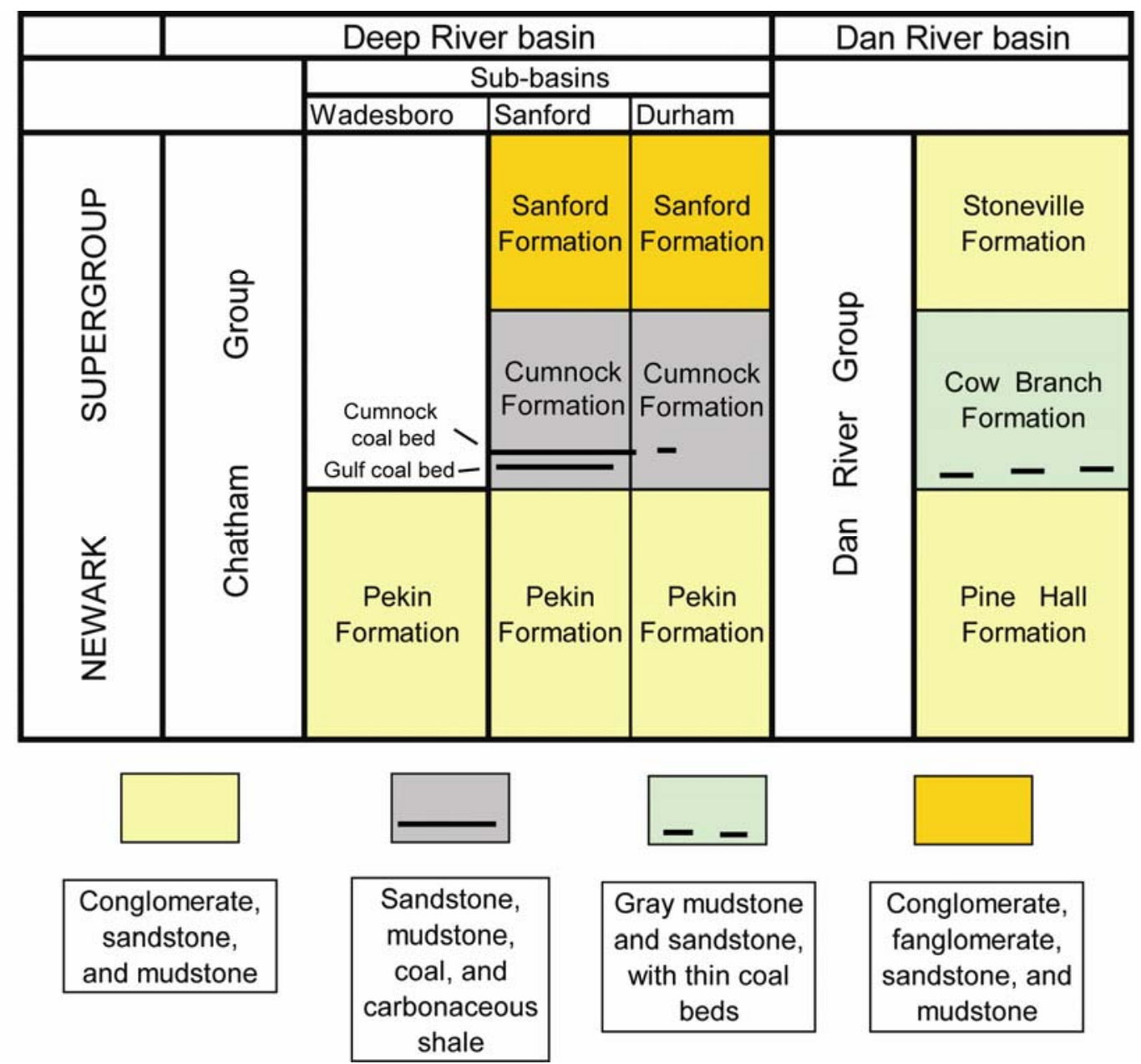

Figure 3. Stratigraphic nomenclature of the Deep River and Dan River Triassic basins, North Carolina (after Reinemund, 1955; Luttrell, 1989; North Carolina Geological Survey, 2006).

The primary exploration target within the Deep River Basin would be the Cumnock Formation, which contains both potential source rocks and reservoirs. The Cumnock may be the host for both conventional and continuous reservoirs. The Cumnock Formation is thickest (750 to 800 feet) in the north central part of the Sanford sub-basin where it contains two coal beds, the Gulf coal and the Cumnock coal. There, the Gulf coal bed is generally less than 2 feet thick; the Cumnock coal bed is typically less than 4 feet thick (Reinemund, 1955). These coal beds are separated by 30 to 40 feet of gray shale, siltstone, and fine-grained sandstone. The coals in this part of the basin are overlain by about 480 to 500 feet of partly fossiliferous and calcareous black and 
gray shale, with minor amounts of sandstone, siltstone, and claystone. They are underlain by about 200 to 260 feet of gray siltstone and fine-grained sandstone. In the western part of the Sanford subbasin, the Cumnock Formation is about 500 feet thick, contains mostly siltstone and sandstone, but no coal. At the south end of the Durham basin, the Cumnock is less than a few hundred feet thick; it consists mostly of silty shale, siltstone, and sandstone, and contains only a few inches of coal. In the Colon cross-structure the Cumnock Formation grades laterally into red and brown sandstone and conglomerate, and is similar to the strata in the Pekin and Sanford formations (Reinemund, 1955, p. 31-33).

Igneous rocks: Late Triassic, or possibly Jurassic, diabasic dikes, sills, and sheet-like bodies are interlayered or intrude the Triassic sedimentary rocks. The dikes are from a fraction of an inch wide to more than 300 feet thick, and are from a few feet to more than 7 miles long. Most dikes trend North $15^{\circ}-40^{\circ}$ West; and a few extend beyond the Deep River basin into the pre-Triassic rocks (Reinemund, 1955). The dikes generally make sharp, straight contacts with the rocks they intrude, but in faulted areas the dikes are usually discontinuous and contacts are irregular. Sills and sill-like intrusives, a few inches thick to more than 100 feet thick, are present in the Sanford subbasin (mostly in the upper part of the Cumnock Formation). They are most extensive in areas of intense faulting in the western part of the coal-bearing area (Reinemund, 1955).

In places, intrusive rocks have metamorphosed the coal beds to semi-anthracite, anthracite, and coke. Because many of the organic geochemistry analyses were from drill holes that penetrated metamorphosed coal and black shale, the maturation indicators are higher than they would have been in strata that were not thermally altered by intrusions. For this reason, much of the available data do not represent the initial organic geochemistry and source rock potential of the Triassic basins in North Carolina, and only data from samples with a relatively low vitrinite reflectance (\%Ro) values may reflect initial TOC values (Reinemund, 1955; Ragland, 1991; Burt and others, 1978).

\section{Dan River Basin}

The Dan River basin is bordered on the northwest by high-angle Mesozoic normal faults that dip steeply to the southeast. Some of these faults apparently follow a reactivated Paleozoic fault zone (Thayer, 1970). The border faults form the contact between the sedimentary fill of the basin and the Paleozoic metamorphic rocks along the northeastern side of the basin. On the southeastern border of the basin, the contact between Triassic strata and the metamorphic rocks of the Piedmont is generally unconformable (Thayer, 1970).

Stratigraphy:- The thickness of the Triassic sedimentary rocks that fill in the Dan River basin may be as much as 15,000 ft, and they consist of conglomerate, sandstone, siltstone, claystone, shale, mudstone, and thin coal beds. These strata were intruded by diabase dikes and sills early in the Jurassic (Luttrell, 1989). The three stratigraphic units that occur in the Dan River basin are, from oldest to youngest, the Pine Hall Formation, the Cow Branch Formation, and the Stoneville Formation (North Carolina Geological Survey, 2006). These formations are within the Dan River Group and Newark Supergroup (fig. 3). The Pine Hall Formation consists mostly of yellowish-orange to brown sandstones, mudstones, and conglomerates that were deposited as fluvial and alluvial clastic sediments. The Cow Branch Formation consists of gray to black, fine- to coarse-grained cyclical lacustrine clastics with thin coal seams at the base. The Cow Branch Formation appears to be the most likely host for conventional and continuous reservoirs within the Dan River Basin. The Stoneville Formation consists of fine- to coarse-grained fluvial and alluvial clastics. The minimum thickness of these stratigraphic units is about 5,000 feet (Thayer, 1970; 
Cornet, 1977). Depth to basement in the vicinity of Stoneville, interpreted from gravity data, is 6,250 feet (Thayer, 1970). The Triassic units dip to the northwest toward the western border fault, which is known as the Dan River fault (Stone, 1912). Thayer (1967) mapped northeastwardtrending cross-faults in the basin and the diabase dikes that commonly intrude them. Pickett (1962) identified a southeast trending anticlinal structure 4 to 6 miles southwest of Leaksville, North Carolina because of the abrupt change in strike of the Cow Branch Formation and a re-entrant in the Dan River fault (North Carolina Geological Survey, 1988).

\section{Organic Geochemistry}

\section{North Carolina Database}

Much of the database of geochemical data for Triassic strata in North Carolina (Appendix A) was compiled from information contributed by industry, universities, and consultants. Other data, which were provided by Brown and Ruth Laboratories (1987), Core Laboratories, Inc. (1983), ARCO Exploration Company (1983a,b, unpublished data; 1984, unpublished data), Texaco (1986, unpublished data), and Textoris (1988, unpublished data), comes from the repository files of the North Carolina Geological Survey (NCGS). Sparse data (Appendix) show the total organic carbon content (weight percent) and other key organic geochemistry parameters, including the hydrogen index (mg HC/g TOC), oxygen index (mg CO $\mathrm{CO}_{2} / \mathrm{g}$ TOC), temperature of maximal hydrocarbon release, Tmax (degrees C), and vitrinite reflectance data (\%Ro) (Tissot and Welte, 1978; Taylor and others, 1998). Table 1 cross indexes Map No., NCGS code, county, well name, other codes, operator, total depth, elevation, latitude, longitude, and other information about the wells from the Triassic in the repository of the North Carolina Geological Survey. NCGS Open-file report 88-1 (Hoffman and Nickerson, 1988) describes the repository organization and access. NCGS Open-file reports 88-2a, 88-2b, which are Database map compilations of well records contained in the repository by Nickerson and Hoffman (1988a,b), supplement Coffey's, (1977) publication on exploratory wells in North Carolina. Figures 1a and 1b shows the locations of wells used in this report.

\section{Oil and Gas Shows}

Hydrocarbon shows occur in four wells, all in the Deep River Basin. These are the V. R. Groce \#1 (map no. 16), Dummit-Palmer \#1 (map no. 17), Butler \#1 (map no. 18), and Bobby Hall \#1 (map no. 20). Multiple shows in each well consist of gas, oil, gas and oil, condensate, or asphaltic material (Figs. 1a, b; Table 1 and Table 2, Appendix A).

The Dummit-Palmer \#1 (LE-OT-1-82) log (North Carolina Geological Survey, unpublished data) states, “...some oil on fractures. Light oil on drilling fluid, has crude oil odor” from a depth of 759 ' 11" to 770'. The log states "Gas blew from the hole when adding rods or pulling core at the intervals 825'-870', 885'-895', 920'-947', and at 952'.” The coal-bed methane potential of this well was summarized by Hoffman and Buetel (1991).

The Butler \#1 gas well was flow tested through a 1/16 ${ }^{\text {th }}$ inch choke on December 14, 1983 (Sherrill, 1984). A gas flow rate of $4 \mathrm{Mcf} /$ day was the calculated stabilized rate of flow from the well. The gas was vented before abandonment and cementing. Small amounts (quarts) of high gravity oil were recovered from the Butler \#1 well. The reported flow point of the oil was 89 
degrees and the formation temperature was 85 degrees (Sherrill, 1984). Laboratory tests showed the oil has high molecular weight paraffin.

Reinemund (1955) presented descriptive logs from thirty diamond drill holes that tested the coal in the Deep River Coal Field. He reported "that some of the shale in the upper part of the Cumnock Formation (which has the highest content of kerogen) may have small drops of oil in interstices or on fresh surfaces, and it may emit small amounts of gas when penetrated by drill holes Reinemund (1955, p. 116).” Reinemund (1955) reported that the shale and blackband (ferruginous, carbonaceous shale) in the Deep River area had an average oil yield of less than 10 gallons of oil per ton, although some beds yield as much as 15 gallons per ton in some parts of the Deep River Coal Field. The oil content is highest in the black shales above the Cumnock coal bed; the oil content of samples of the blackband associated with the Cumnock coal bed range from a trace to 15.9 gallons per ton in the beds near the Cumnock coal. The blackband associated with the Gulf coal bed has yielded as much as 14.9 gallons per ton. Reinemund (1955) recalculated the data of Vilbrandt (1927), which showed that the beds above the Cumnock coal bed had an oil content of as much as 12.7 gallons per ton. Bain and Brown (1981, p. 90) reported an oil saturation of 3.25 percent from drill hole BH-9 in the Durham sub-basin, at a depth of 475 feet.

\section{Total Organic Carbon (TOC)}

Total organic carbon (TOC) data is the most common parameter in the organic geochemistry database (Appendix, fig. 4). The minimum amount of organic matter necessary to generate and expel oil from a shale source rock ranges generally from $0.4 \%$ to $1.4 \% \mathrm{TOC}$, and is probably closer to the higher of these two values (Ronov, 1958; Dow, and O'Conner, 1982). TOC data show that virtually all of the samples in the database are above the lower limit of 0.4 weight percent total organic carbon. The spread of the data, however, reflects the wide range of geological conditions under which the source rocks were deposited and preserved in the Triassic basins of North Carolina. Both the Cow Branch Formation (Dan River Basin) and the Cumnock Formation (Sanford sub-basin) contain potential source rocks. Although TOC data (Appendix) that are greater than the $1.4 \%$ threshold for hydrocarbon expulsion suggest that either formation could contain potential source rocks for petroleum, they are more likely to be sources for natural gas because their relatively high thermal maturation and abundance of type III kerogen (Appendix; fig. 5) (Tissot and Welte, 1978). 

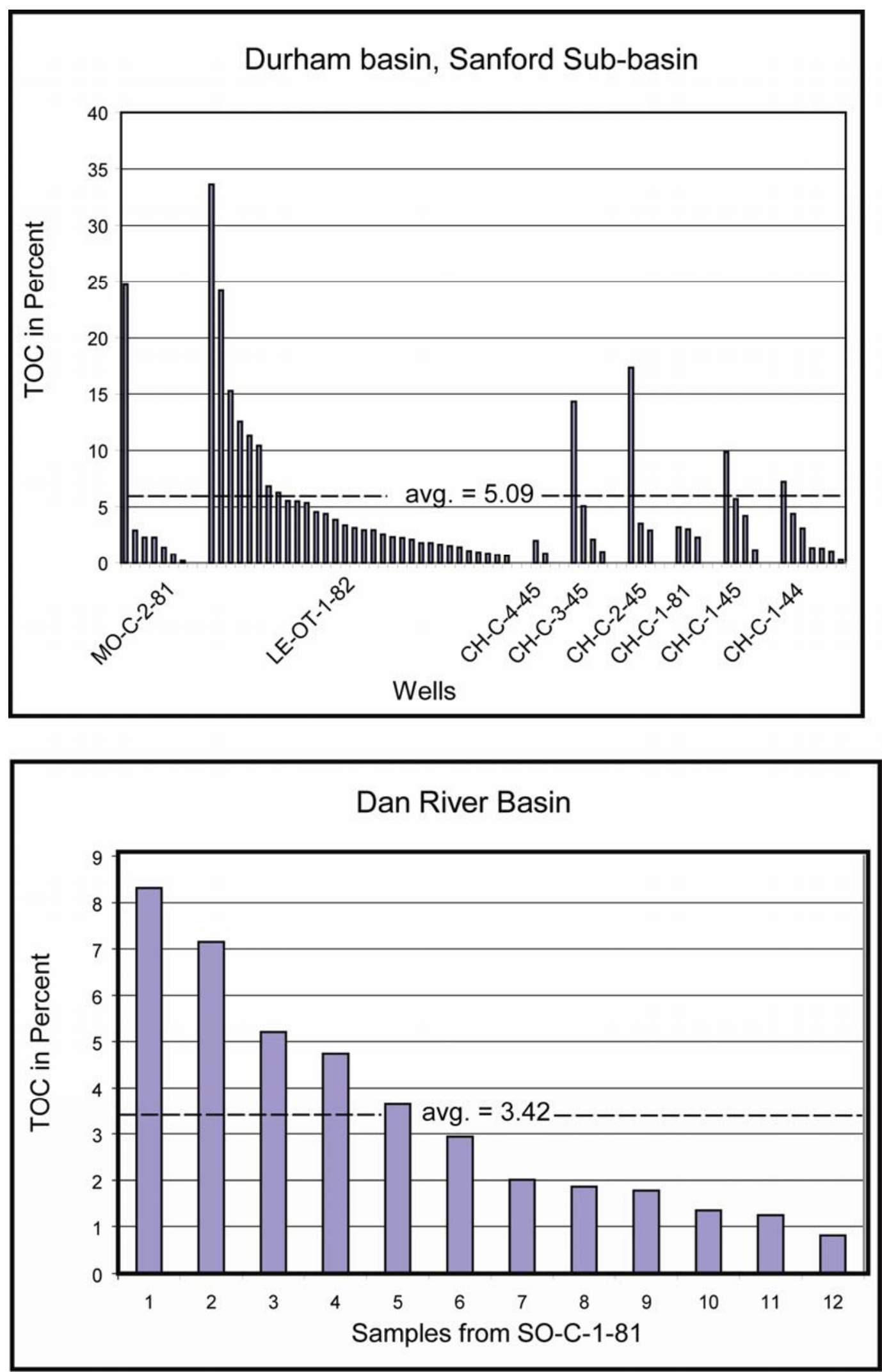

Figure 4. Distribution of TOC data from wells in the Dan River and Durham basins. 
TOC of the Cow Branch Formation (Dan River Basin):- TOC data are limited to one drill hole (SO-C-1-81; map no. 26, fig. 1a) that penetrated the Cow Branch Formation in the Dan River Basin. TOC values ( $n=12)$ average 3.42 weight percent and range from 0.81 to 8.31 weight percent. The standard deviation is 2.45 weight percent.

TOC of the Cumnock Formation (Deep River Basin):- TOC of the Cumnock Formation $(\mathrm{n}=$ 66) averages 5.17 weight percent and ranges from 0.20 weight percent to 33.62 weight percent. The standard deviation is 6.43 weight percent. These data are from five drill holes. No TOC data are available for the Pekin or Sanford Formations.

\section{Hydrogen, Oxygen, and Carbon Data}

$\mathrm{HI} / \mathrm{Ol}$ indices - The organic matter type, determined by the hydrogen index [HI] and the oxygen index [OI], shows the nature of the hydrocarbon (oil, gas, or both) most likely to be generated by a source rock. Type I organic matter (algal, lacustrine) generates primarily oil; type II (marine, reducing environment) generates both oil and gas, and type III (plant derived) generates primarily gas (Tissot and Welte, 1978, p. 447). The indices for available data are plotted by basin in figure 5; see also Appendix. The curved lines indicate approximate thermal evolution pathways for organic matter types I, II and III (modified Van Krevelen diagram from Tissot and Welte, 1978). 


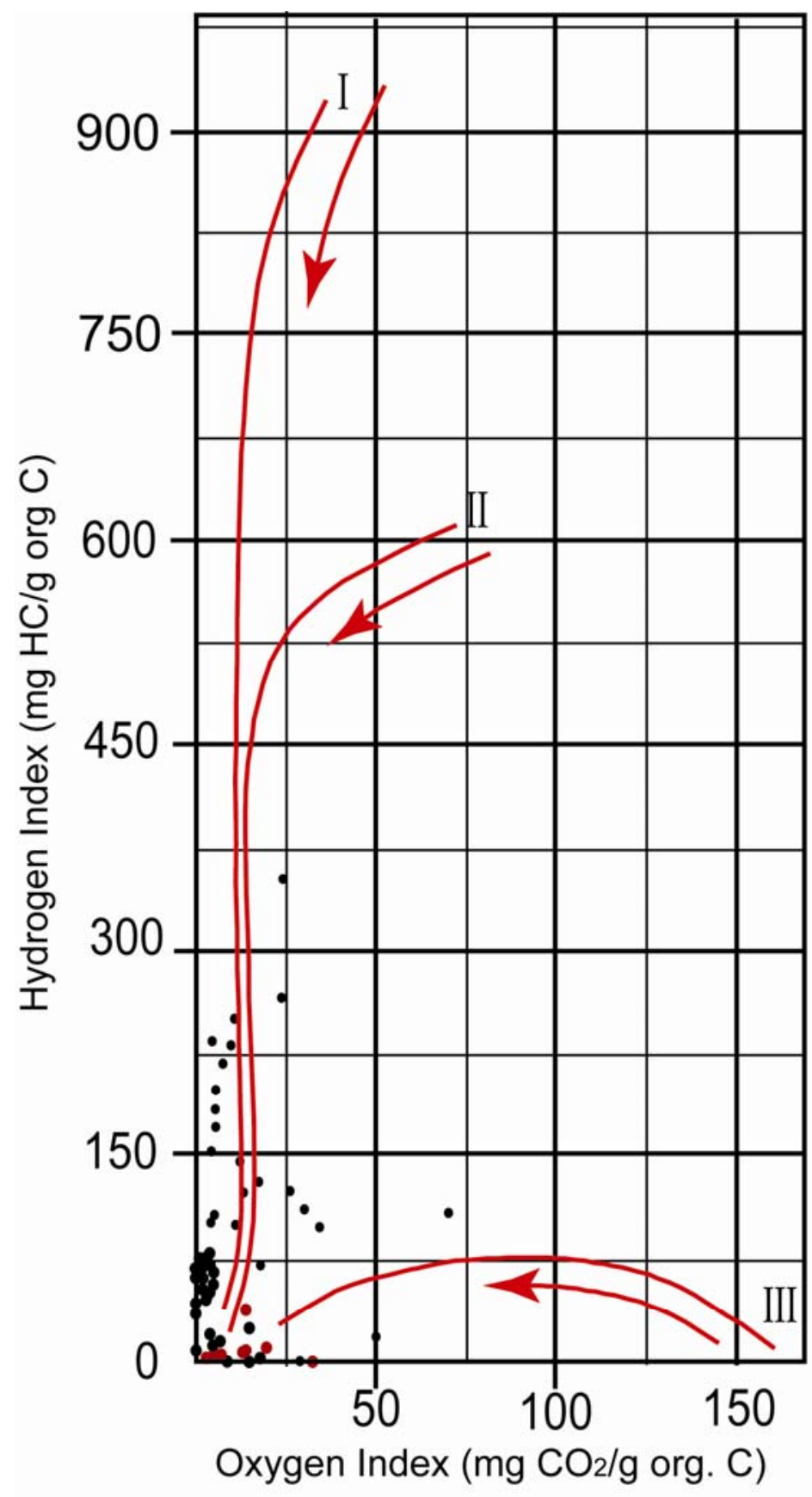

Figure 5. Plot of hydrogen and oxygen indices from Rock-Eval pyrolysis in relation to primary kerogen type (shown by Roman numerals). Main evolutionary pathways are indicated by red arrows (Tissot and Welte, 1978) - Deep River basin (black) Dan River basin (red).

$\mathrm{H} / \mathrm{C}-\mathrm{O} / \mathrm{C}$ ratios - Hydrogen/carbon (H/C) and oxygen/carbon (O/C) ratios for well CH-C1-44 (fig. 1, map no. 1) are shown in figure 6 . The curved lines in figure 6 , supplemented by data 
plots of vitrinite reflection in \%Ro vs. depth (Figure 7), show the approximate thermal evolution pathways for organic matter types I, II, and III.

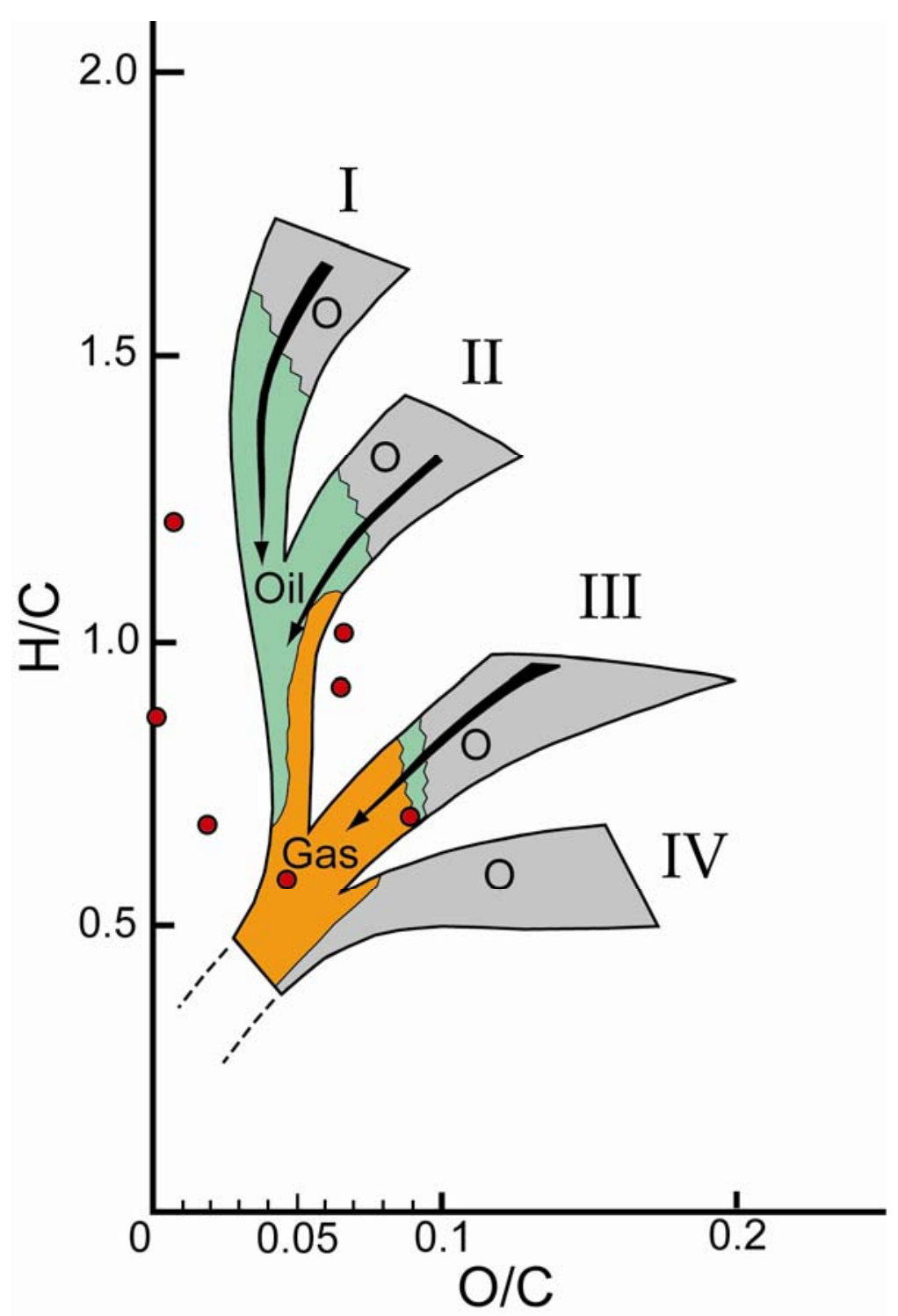

Figure 6. $\mathrm{H} / \mathrm{C}$ and $\mathrm{O} / \mathrm{C}$ ratios of kerogen types I - IV. Type I is floccules collalginite, or sapropelic; type II is liptinite, except alginite; type III is "low-gray" vitrinite, and type IV is fusinite and "high gray" material. Arrows show evolution paths of increasing maturity. $\mathrm{O}$ represents the formation of oxygenated products $(\mathrm{CO} 2, \mathrm{H} 2 \mathrm{O}$, heavy heteroatomic molecules); Oil - petroleum formation; Gas - gas formation (after Bostick,1979, who modified this diagram by Tissot and Espitalie,1975). Data (red circles) are from well $\mathrm{CH}-\mathrm{C}$ 1-44, Cumnock Formation, Sanford sub-basin of the Deep River basin 

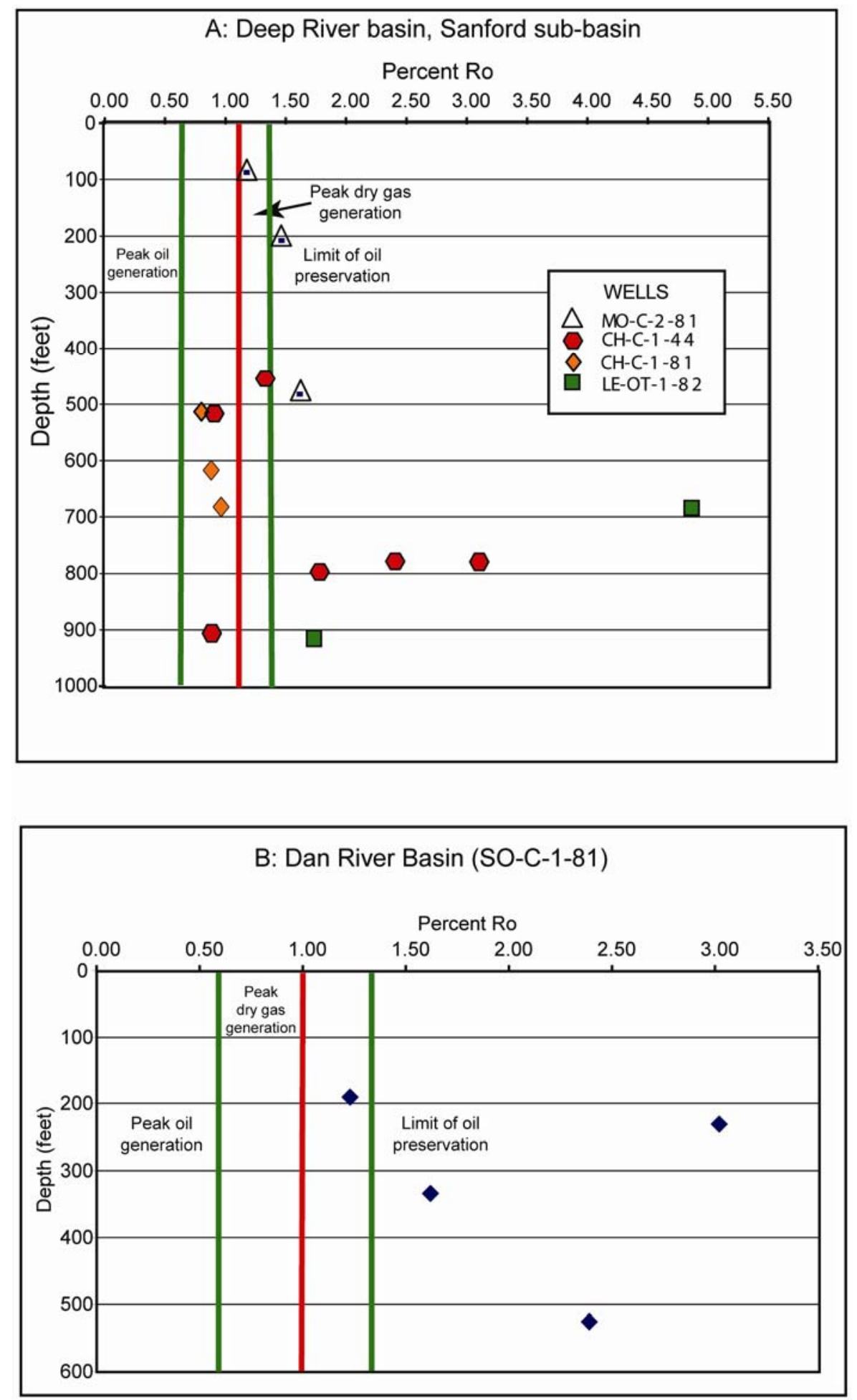

Figure 7. Plot of depth vs. \%Ro for selected wells in the Dan River and Deep River basins, showing the relationship of thermal maturity, measured as \%Ro, to depth. Hydrocarbon generation and preservation limits from Houseknecht and Spotl (1993 


\section{Vitrinite Reflectance Data (\%Ro)}

Vitrinite reflectance values are available for drill holes from both the Sanford sub-basin of the Deep River basin and the Dan River basin (fig. 7 a, b). Data are not available for the other Triassic basins in North Carolina. The vitrinite reflectance data (\%Ro) are similar to TAI data. They have similar maturity and hydrocarbon generation patterns, and both data sets exhibit anomalous values (Appendix). Vitrinite reflectance profiles commonly are variable and the data from some of the wells exhibit sharp vitrinite reflectance peaks (fig. 7). These patterns indicate locally steep thermal gradients; some well descriptions report contact metamorphic effects on the sedimentary strata that were caused by intrusive diabase bodies, many of which were cut by the drill hole (Reinemund, 1955, p. 60-61). 

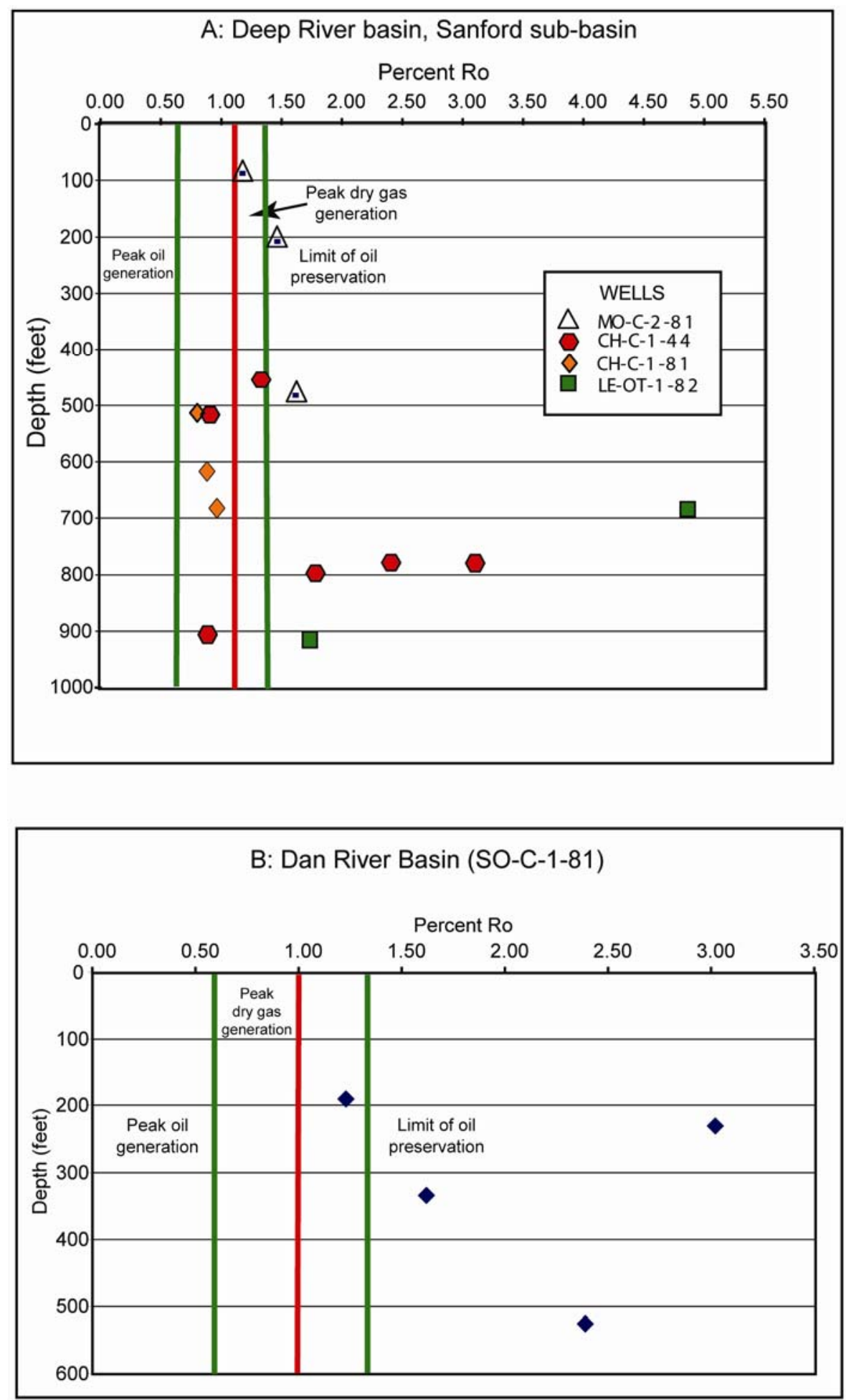

Figure 7. Plot of depth vs. \%Ro for selected wells in the Dan River and Deep River basins, showing the relationship of thermal maturity, measured as \%Ro, to depth. Hydrocarbon generation and preservation limits from Houseknecht and Spotl (1993

Vitrinite reflectance data from four samples in one Dan River drill hole (SO-C-1-81) (Appendix) average $2.07 \%$; the range is $1.23 \%$ to $3.02 \%$ with a standard deviation of $0.80 \%$. 
These data represent hydrocarbon generation from peak dry gas generation to the upper limits of dry gas preservation.

Vitrinite reflectance data from the Cumnock Formation in the Sanford sub-basin average $1.73 \%$ and range from $0.80 \%$ to $4.85 \%$ with a standard deviation of $1.16 \%$. The data are from three wells in this basin (Appendix). Drill hole CH-C-1-44 (USBM number DH-D1) (fig. 1b, map no. 1) has vitrinite reflectance data from the Cumnock Formation that ranges from $0.91 \%$ to $3.11 \%$. Drill hole CH-C-1-81 (fig. 1b, map no. 3) has vitrinite reflectance data from the Cumnock Formation that range from $0.80 \%$ to $0.96 \%$. Drill hole LE-OT-1-82 (fig. 1b, map no. 17) (Drummit-Palmer \#1 well), which is located about one-quarter mile away, has two samples from the Cumnock Formation with vitrinite reflectance values of $4.85 \%$ and $1.72 \%$. Drill hole MO-C-281 (fig. 1b, map no. 22) has three vitrinite reflectance data points in the Cumnock that range from $1.17 \%$ to $1.61 \%$.

The data show hydrocarbon generation potential over a wide range of conditions. Drill hole CH-C-1-44 has a wide range of vitrinite reflectance. Its data range from oil and peak wet gas generation $(\% \mathrm{Ro}=0.9)$ to the limits of dry gas generation $(\% \mathrm{Ro}=3.11)$. Drill hole $\mathrm{CH}-\mathrm{C}-1-81$ has a restricted range of vitrinite reflectance, from the peak oil generation $(\% \mathrm{R} 0=0.80)$ to the onset of peak wet gas generation $(\%$ Ro $=0.96)$. Drill hole LE-OT-1-82 data indicate thermal maturation values that range from wet or dry gas generation $(\% \mathrm{Ro}=1.72)$ to beyond the limit of gas preservation $(\% \mathrm{Ro}=4.85)$.

\section{Thermal Alteration Index}

Thermal alteration index (TAI) and vitrinite reflectance (\%Ro) data are in the Appendix. Both sparse TAI thermal maturation data (drill hole CH-C-1-44 (fig. 1b, map no. 1, Sanford subbasin) and more common \%Ro data show a wide range of values. The TAI data show thermal maturation ranks that range from peak dry gas generation (TAI $=3$ ) nearly to the limit of dry gas preservation (TAI = 3.7) (Taylor and others, 1998).

\section{Genetic Potential}

Genetic potential (S1 + S2, mg HC/g sample) (Appendix) is a summary measure of hydrocarbon-generating potential that depends on organic matter amount, type, and thermal maturity. S1 is the fraction of the organic matter that has been transformed into hydrocarbons. S2 is the residual potential that has not been used to generate hydrocarbons (Espitalie and others, 1977; Tissot and Welte, 1978). Tissot and Welte (1978, p.447) suggest the following classification of genetic potential (S1 + S2, mg HC/g sample):

$<2 \mathrm{mg} / \mathrm{g}$ : Little or no source rock potential

2-6 mg/g: Moderate source rock potential

$>6 \mathrm{mg} / \mathrm{g}$ : Good source rock potential

Based on this classification, genetic potential data (Appendix) span all ranges. Potential source rocks have at least moderate source rock potential and commonly have good source rock potential. Some of the data from the Cumnock Formation indicate a considerably higher source rock potential than others, with S1 + S2 values in the mid- $20 \mathrm{mg} \mathrm{HC/g}$ sample range. Hydrocarbon shows illustrate that some oil and natural gas was generated, and it is possible that hydrocarbons may have been generated in commercial amounts, especially if the genetic potential for these rocks was higher prior to diabase intrusion and thermal metamorphism. 
A comparison of Tmax with hydrogen index (HI) values (fig. 8) indicates that these samples from the Durham basin, Sanford sub-basin may be divided into two broad groups, those with HI values greater than 150 and Tmax temperatures in excess of $435^{\circ} \mathrm{C}$, the onset of hydrocarbon generation (Taylor and others, 1998), and those with HI values less than 150. The former are thermally mature and likely represent oil-prone source rocks. Of the latter group, those with Tmax values $>435^{\circ} \mathrm{C}$ are thermally mature, but their relatively low HI values indicate that they may represent gas-prone source rocks. The two fields with both low HI and Tmax values contain questionable data points.

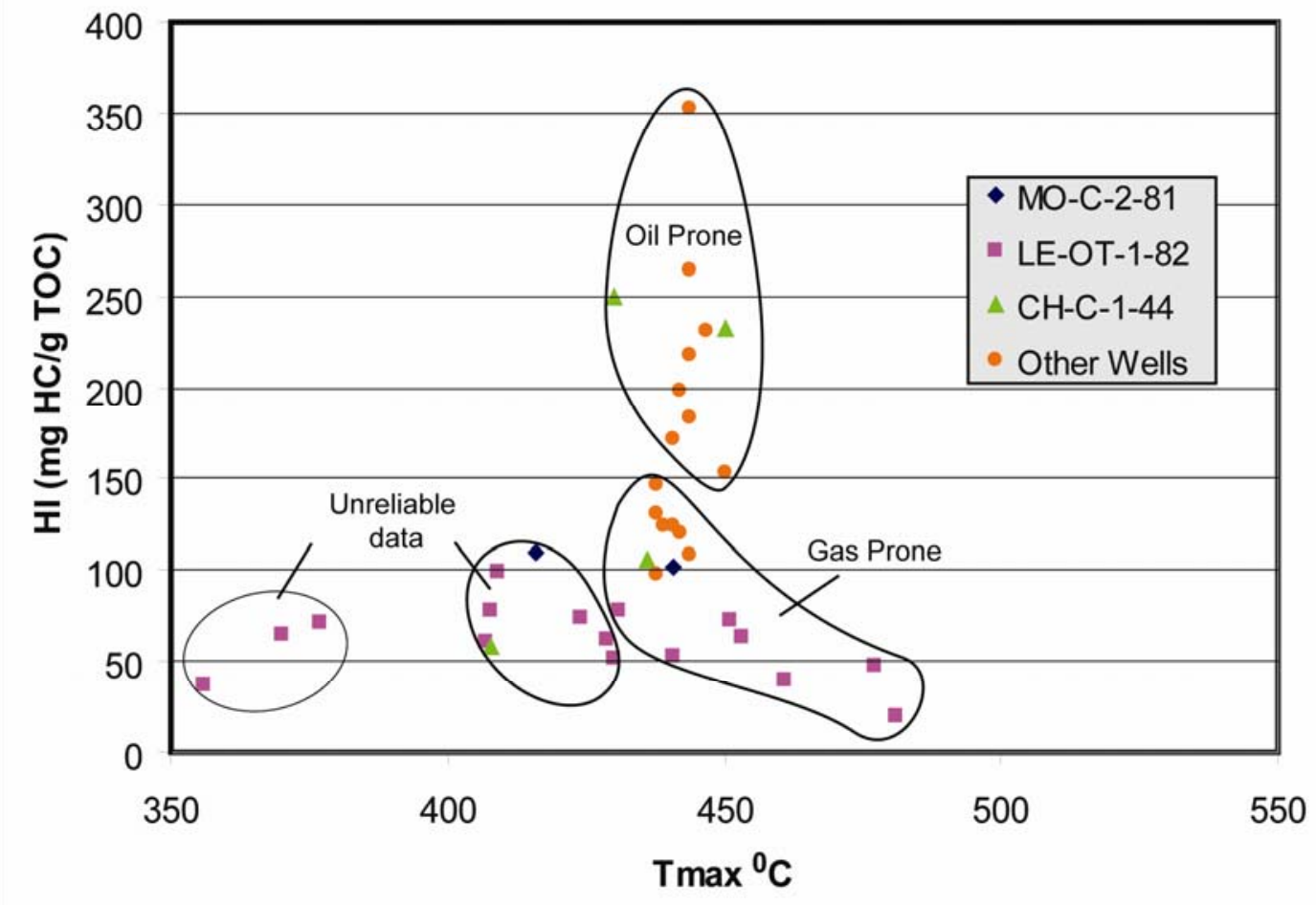

Figure 8. Comparison of Tmax and Hydrogen Index of samples from wells in the Durham basin, Sanford sub-basin 


\section{Reservoirs}

Potential reservoirs include conventional stratigraphic traps and structural traps in folded and fractured sandstones, perhaps sealed by shale beds and intrusive and extrusive (layered) igneous rocks, and continuous reservoirs in coal beds and lacustrine shale beds. Basin faulting and cross faulting may provide structural traps for small natural gas accumulations, and sealed fractured reservoirs in these Triassic sedimentary rocks might be suitable for testing by horizontal drilling. In some places, intrusive igneous rocks may have induced fractures in adjacent sandstone beds, enhancing their capacity to produce hydrocarbons. In other places, intrusives and their contact metamorphic aureoles may provide seals for gas accumulations. Elsewhere, fracture zones in the thermal aureoles surrounding intrusives may serve as migration pathways for gas.

\section{Porosity and Permeability}

Porosity and permeability data are limited to drill holes CH-C-1-81 (map no. 3), CH-C-2-81 (map no. 5), CH-C-4-45 (map no. 7), and MO-C-2-81 (map no. 22) (fig. 1b, Appendix). All of these drill holes are in the Sanford sub-basin. Measured porosity and permeability are low, $<0.1$ 2.20\% and 1.3-8.1 md, respectively. Triassic sedimentary rocks in the North Carolina basins generally have low porosity and permeability. For example, water wells in Triassic-age rocks are successful only if fractures are encountered Daniel (1987). Daniel (1987) showed that the water yields for wells drilled in Triassic sedimentary strata were the lowest for any of the hydrologic units that he had studied in the Piedmont of North Carolina. Daniel and Payne (1990) identified 18 hydrogeologic units in the Piedmont and Blue Ridge of North Carolina. Of these, the Triassic rocks had the lowest average yield (about 12 gallons per minute). Because intergranular porosity and permeability are generally low, hydrocarbon exploration should target potential reservoirs that are enhanced by fracture porosity.

Bain and Brown (1981) evaluated the Durham Triassic basin to characterize its potential for waste-storage. They observed that the Triassic rocks of the basin have low porosity and permeability and that much of the primary porosity was lost through diagenesis, lithification, and compaction. They also presented porosity and permeability data from the Sears No.1 well (Table 1, fig. 1a, map no. 28), which showed that porosities determined from geophysical logs had little relationship to laboratory core data from equivalent depths. The range of laboratory-determined gas porosity for this well was from 0.83 to 12 percent and averaged 3.5 percent.

\section{Discussion}

In general, the geologic and geochemical data support the concept of two active petroleum systems in the Triassic basins of North Carolina, the Cumnock-Chatham Group composite Total Petroleum System in the Deep River basin, and the Cow Branch-Dan River Group composite Total Petroleum System in the Dan River basin. Potential source rocks are the coal beds and dark shales rich in organic matter. Each of these basins exhibits a potential for conventional accumulations of hydrocarbons in fractured reservoirs as well as a potential for continuous accumulations of methane in coal beds and shales rich in organic matter. Possible conventional exploration plays include: (1) fractured reservoirs sealed by surrounding low porosity and permeability sedimentary and igneous rocks, and (2) fold and fault-controlled structural plays.

Hydrogen/carbon (H/C) and oxygen/carbon (O/C) ratios, and hydrogen and oxygen indices of organic matter from the Deep River and Dan River basins plot generally in the type I (algal) and type III (plant material) evolutionary pathways, respectively. These source rocks could produce 
both gas and oil, with a higher potential for oil in the Deep River basin. Oil-prone, hydrogen-rich source materials can produce hydrocarbons of any type (oil, condensate, or gas) under the correct conditions and will ultimately produce the greatest volume of hydrocarbons of any kerogen type. Although type III kerogen is less prone to produce oil than the others, it is favorable for the production of gas (Tissot and Welte, 1978).

Figure 9 is a correlation of hydrocarbon generation, vitrinite reflectance (\%Ro), type of organic matter, and TAI. Zones of petroleum generation and destruction are shown. Almost all of the vitrinite reflectance data illustrated in figure 7 are within the oil and gas windows. The main zone of oil generation (oil window) occurs when vitrinite reflectance values (\%Ro) range from $0.5 \%$ to $1.3 \%$ (fig. 9), which corresponds to Tmax values that range from $430^{\circ} \mathrm{C}$ to $460^{\circ} \mathrm{C}$ (Tissot and Welte, 1978, p. 450-455). For the Sanford sub-basin, \%Ro data ranges from the upper part of the oil generation window to primarily that of gas generation (fig. 7a). For the Dan River basin, data range from the upper limit of the oil generation window to near the limit of the preservation of dry gas (fig. 7b). Almost all available Tmax data from the Sanford sub-basin (fig. 8) range generally between 400 and 500 degrees C. Anomalous data that resulted from thermal heating by diabase rocks are beyond the dry gas preservation field. 


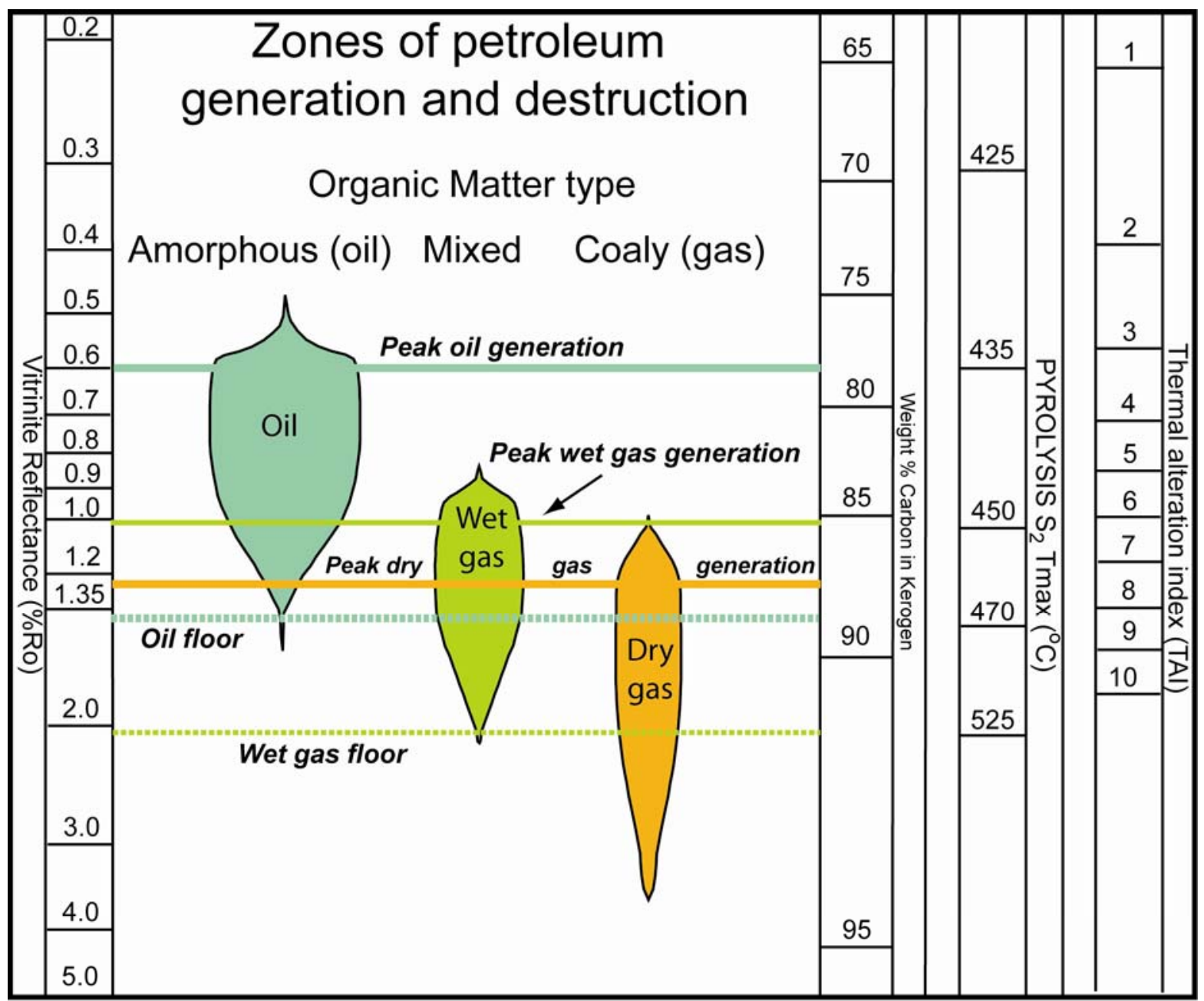

Figure 9. Thermal maturation indices and zones of hydrocarbon generation and destruction (modified slightly from Dow and O'Conner, 1982).

There is much information that shows that the strata within the eastern Mesozoic basins contain lots of plant debris as well as coal, so that source rocks would be expected to contain a considerable amount of Type III kerogen. For example, Textoris, Robbins, and Gore (1989) stated that the TOC of the coals in an unnamed eastern Triassic basin ranges from $12 \%$ to $80 \%$, and that the carbonaceous shales, dominated by woody material, had a TOC from $4 \%$ to $34 \%$; no localities were provided. They also reported TAI values that range from 3 to 4 , and \%Ro values that range 
from $0.8 \%$ to $1.5 \%$. These data indicate that there are thermally mature hydrocarbon source rocks in the basin. Palynological studies showed that the spores in their samples were dominated by seed ferns and ferns, and that the samples consisted primarily of wood cells and gelified wood. The carbonaceous shales that they studied represent marsh facies also dominated by wood cells.

Robbins and Textoris (1988a) studied the coal of the Deep River basin. They found that the carbonaceous marsh deposits underlying the coal beds are dominated by the remains of ferns and cycads, whereas the coal is dominated by seed ferns and conifers, which may represent "swamp" vegetation. Both studies found that the lacustrine shales that overlie the individual coal beds are rich in algal kerogen, which enhances the petroleum potential of the basin.

Robbins and Textoris (1988b) studied the Cumnock Formation in the Dummit-Palmer \#1 well (LE-OT-1-82) (Appendix) and found that the pyritic sulfur content was variable but generally low in concentration. They reported that the contact metamorphic effects of the diabase sill on the organic matter resulted in a progressive degradation of the organic tissues and concluded from the identification of the clay minerals that the shales were deposited in a chemically reducing environment. Robbins and Textoris (1988b) provided information on the types of kerogen, thermal alteration, biostratigraphy, TOC and other parameters in the Dummit-Palmer \#1 well. Overall, they concluded that woody plants were the source of the gas shows in the well.

Highly generalized organic geochemistry parameters were provided by Robbins and Textoris (1986). Thermal alteration index data (cited from Phillips Petroleum files, Pearson, 1981) from five unspecified outcrops and from one core sample (possibly from the Cumnock Formation?) ranged from " $2+$ to $3+$ ". Related vitrinite reflectance data range from $0.8 \%$ to $1.5 \%$ from these same rocks. Robbins, Wilkes, Textoris (1988) studied coal deposits of the Newark Rift system and concluded that the woody plants present are similar to those found around modern rift lakes.

\section{Conclusions}

- Organic geochemistry shows source rocks in the Deep River and Dan River basins are both oil and gas prone. Organic matter is both lacustrine and terrestrial in origin. The terrestrial organic matter is woody in nature.

- Available hydrogen/carbon (H/C) and oxygen/carbon (O/C) ratios in the Dan River and Deep River basins plot primarily in the type I, II, and type III evolutionary pathways. Because of elevated thermal maturity, however, the source rocks would primarily produce natural gas rather than oil.

- The Triassic sedimentary rocks generally have low interstitial porosity and permeability, which may, in places, be enhanced by fracture porosity. Horizontal drilling may be useful in exploring for fractured reservoirs.

- Diabasic intrusions (dikes and sills) are abundant. Intrusions heated the source rocks both regionally and locally, which resulted in thermal overmaturity of organic matter in many places. Available organic geochemical data are limited to a few wells in which intrusives are present so that the source rocks tested do not reflect their original hydrocarbongenerating potential.

- In some places, diabase intrusives and extrusives (dikes and sheets) may form seals for smaller plays. 
- Areas prospective for natural gas also contain large clay resources. The gas could be used as a fuel for local industries that produce clay products, and possibly for other local industries, such as brick drying.

\section{Acknowledgments}

Michael Dixon verified data from repository files. Various contributions were received from C. W. Hoffman and L. Zarra. Brandie Harmon provided assistance in publication preparation. Reviews from Robert C. Burruss and Sharon M. Swanson (U.S. Geological Survey, Reston, VA), Dan Miller (Chapel Hill, NC) and others strengthened this report. C.W. Hoffman (NC Geological Survey) provided access to the repository files.

\section{References Cited}

ARCO, 1983a, Unpublished letter and data transmittal of August 16, 1983 to Richard V. Smith from Don C. Ottensman.

ARCO, 1983b, Unpublished letter and data transmittal of November 21, 1983 to Charles W. Hoffman from Don C. Ottensman.

ARCO, 1984, Unpublished letter and data transmittal of June 26, 1984 to Charles W. Hoffman from Ken O. McDowell.

Bain, G.L., and Brown, C.E., 1981, Evaluation of the Durham Triassic basin of North Carolina and Techniques Used to Characterize its Waste Storage Potential: U. S. Geological Survey Open-File Report 80-1295, 138 p.

Bostick, N.H., 1979, Microscopic measurement of the level of catagenesis of solid organic matter in sedimentary rocks to aid exploration for petroleum and to determine former burial temperatures - A review: S.E.P.M. Special Publication, No. 26, p. 17-43.

Brown and Ruth Laboratories, Inc., 1987, Letter with attached data transmittal and report of December 2, 1987 to Geogry C. Reid (sic) from Gary W. Ruth.

Burt, E.R., Carpenter, P.A., III, McDaniel, R.D., and Wilson, W.F., 1978, Diabase Dikes of the Eastern Piedmont of North Carolina: North Carolina Geological Survey Information Circular 23, 12 p. text plus map compilation.

Campbell, M.R. and Kimball, K.W., 1923, The Deep River Coal Field of North Carolina: North Carolina Geological and Economic Survey Bulletin 33, 95p., prepared by the United States Geological Survey in cooperation with the North Carolina Geological and Economic Survey.

Coffey, J.C., 1977, Exploratory Oil Wells of North Carolina, 1925-1976, North Carolina Geological Survey, Information Circular 25, 52p.

Core Laboratories, Inc., 1983, Unpublished letter and data transmittal of November 14, 1983 to Don C. Ottensman from Louie G. Beam. 
Cornet, Bruce., 1977, The palynostratigraphy and age of the Newark Supergroup: Ph.D. thesis, University of Pennsylvania, State College, Pennsylvania, 505p.

Daniel, C.C. III, 1987, Statistical analysis relating well yield to construction practices and siting of wells in the Piedmont and Blue Ridge Provinces of North Carolina: U. S. Geological Survey Water Resources Investigations Report 86-4132, 54p.

Daniel, C.C. III and Payne, R.A., 1990, Hydrogeologic unit map of the Piedmont and Blue Ridge Provinces of North Carolina: U. S. Geological Survey Water-resources Investigations Report 904035, scale 1:500,000.

Dolton, G.L., Takahashi, K.I., and Varnes, K.L., 1995, National Assessment of United States oil and gas resources-results, methodology, and supporting data: U.S. Geological Survey Digital Data Series DDS-30.

Dow, W.G., and O’Connor, D.I., 1982, Kerogen maturity and type by reflected light microscopy applied to petroleum exploration, in Staplin, F. L., and other, How to Assess Maturation and Paleotemperatures: Society of Economic Paleontologists and Mineralogists, Short Course Number 7, p. 133-158 ([sic] - last page blank and unnumbered).

Espitalie, J., Laporte, J. L., Madec, M., Marquis, F., Leplat, P., Paulet, J., and Boutefeu, A., 1977, Methode rapide de caracterisation des roches meres, et de leur potentiel petrolier et de leur degre d’evolution: Revue de l’Institut Francis de Petrole, v. 32, p. 23-42.

Froelich, A.J., and Robinson, Gilpin, Jr., editors, 1988, Studies of the Early Mesozoic basins of the eastern United States: U. S. Geological Survey Bulletin 1776, 423p.

Hoffman, C.W., and Buetel, R.A., 1991, The Dummitt-Palmer \#1 Coal-bed methane test well, Lee County, North Carolina: North Carolina Geological Survey Open-File Report 91-1, 11p.

Hoffman, C.W. and Nickerson, J.G., 1988, North Carolina Geological Survey Sample Repository of Core, Cuttings and Well Logs: North Carolina Geological Survey, Open-file Report 88-1.

Houseknecht, D.W., and Spotl, Christoph, 1993, Emperical observations regarding methane deadlines in deep basins and thrust belts, in Howell, D.G., ed. The future of energy gases: U.S. Geological Survey Professional Paper 1570, p. 217-231.

Luttrell, G.W., 1989, Stratigraphic nomenclature of the Newark Supergroup of Eastern, North America, U. S. Geological Survey Bulletin 1572, 136p.

Margolis, Jacob, Robinson, G. R., Jr., and Schafer, C. M., 1988, Annotated bibliography of studies on the geology, geochemistry, mineral resources, and geophysical character of the Early Mesozoic basins of the Eastern United States, 1880-1984: U. S. Geological Survey Bulletin 1688, 492p. 
Milici, R.C., Bayer, K.C., Pappano, P.A., Costain, J.K., Coruh, Cahit, and Nolde, J.E., 1991, Preliminary geologic section across the buried part of the Taylorsville basin, Essex and Caroline Counties, Virginia: Virginia Division of Mineral Resources Open File Report 91-1, 31p.

Milici, R.C., 1995, The Blue Ridge thrust belt (068), Piedmont Province (069), Atlantic Coastal Plain Province (070), Adirondack Province (071) and New England Province (072), in Gautier, D. L., Dolton, G. L., Takahashi, K. I., and Varnes, K. L., 1995 National Assessment of United States oil and gas resources-results, methodology, and supporting data: U.S. Geological Survey Digital Data Series DDS-30.

Myertons, C.T., 1963, Triassic formations of the Danville basin: Virginia Division of Mineral Resources Report of Investigation 6, 65 p.

Nickerson, J.G., 2007, Scanned well logs for Lee County, North Carolina, unpublished data, personal communication to Reid.

Nickerson, J.G. and Hoffman, C.W., 1988a, North Carolina Geological Survey Database Maps, Sheet 1: Raleigh $1^{\circ}$ x $2^{\circ}$ Quadrangle, North Carolina Geological Survey Open-File Report 88a.

Nickerson, J.G. and Hoffman, C.W., 1988b, North Carolina Geological Survey Database Maps, Sheet 1: Florence $1^{\circ} \mathrm{x} 2^{\circ}$ Quadrangle, North Carolina Geological Survey Open-File Report 88-b. North Carolina Geological Survey, 1985, Geologic Map of North Carolina, scale 1:500,000 in color.

North Carolina Geological Survey, 1988, Preliminary explanatory text for the 1985 Geologic Map of North Carolina, Contractual Report 88-1, November 4, 1988, 271 p.

North Carolina Geologic Survey, 2006, Geologic map of North Carolina: http://www.geology.enr.state.nc.us/usgs/geomap.htm (accessed November 2006).

Pickett, T.C., 1962, Stratigraphy of the Dan River Triassic basin in North Carolina, unpublished thesis: University of North Carolina, Chapel Hill, 54p.

Ragland, P.C., 1991, Mesozoic Igneous Rocks, in, Horton, J. W., Jr. and Zullo, V.A., editors, The Geology of the Carolina: Carolina Geological Society Fiftieth Anniversary Volume, University of Tennessee Press, Knoxville, pages 171-190.

Randazzo, A.F., and Copeland, R.E., 1976, The geology of the northern portion of the Wadesboro Triassic basin, North Carolina: Southeastern Geology, v. 17, no. 3, p. 115-138.

Reinemund, J.A., 1955, Geology of the Deep River Coal Field, North Carolina, U. S. Geological Survey Professional Paper 246, 156p.

Robbins, E. I., 1982, "Fossil lake Danville”: The paleoecology of a Late Triassic ecosystem on the North Carolina-Virginia border, unpublished dissertation, the Pennsylvania State University, 400p. 
Robbins, E. I., and Textoris, Daniel A., 1986, in Gore, Pamela, J. W., editor, Depositional Framework of a Triassic Rift basin: The Durham and Sanford Sub-basins of the Deep River basin, North Carolina, Field Trip \#3, September 24-25, 1986, The Society of Economic Paleontologists and Mineralogists, Third Annual Midyear Meeting, Raleigh, North Carolina, p. 75-79.

Robbins, E.I., and Textoris, Daniel (sic) I., 1988a, Origin of Late Triassic Coal in the Deep River basin of North Carolina (USA), IAS International Symposium on Sedimentology Related to Mineral Deposits (Abstracts), Beijing, China, p. 219-220.

Robbins, E. I. And Textoris, Daniel A., 1988b, Analysis of kerogen and biostratigraphy of core from the Dummit-Palmer No. 1 well, Deep River basin, North Carolina: US Geological Survey Open-File Report 88-670, 15p.

Robbins, E. I., Wilkes, G.P., and Textoris, D.A., 1988, Coal Deposits of the Newark Rift System in Manapiezer, W., (editor) Triassic-Jurassic Rifting (Continental Breakup and the Origin of the Atlantic Ocean and Passive Margins), Part B: Developments in Geotectonics 22, Elsevier, Chapter 27, p. 649-682.

Ronov, A.B., 1958, Organic carbon in sedimentary rocks (in relation to presence of petroleum): Translations in geochemistry, v. 5, p. 510-536.

Schruben, P.G., Arndt, R.E., and Bawiec, W.J., 2006, Geology of the conterminous United States at 1:2,500.000 Scale - A digital representation of the 1974 P.B. King and H.M. Beikman map: U.S. Geological Survey Digital Data Series 11, Release 2.

Sherrill, C.E., 1984, Unpublished letter to Stephen G. Conrad of August 3, 1984.

Staplin, F.L., 1977, Interpretation of thermal history from color of particulate organic matter - a review; Palynology, v. 1. p. 17 (not seen).

Stone, R.W., 1912, Coal on Dan River, North Carolina: U. S. Geological Survey Bulletin 471-B, p. 137-169.

Taylor, G.H., Teichmüller, M., Davis, A., Diessel, C.F.K., Littke, R., and Robert, P., Organic petrology, Gebrüder Borntraeger, Berlin, 704 p.

Texaco, 1986, Unpublished letter and data transmittal of November 11, 1986 to Charles W. Hoffman from Michael A. Smith.

Textoris, W.A., 1988, Written communication from W. A. Textoris to J. C. Reid transmitting TOC data from the Dummitt-Palmer No. 1 well. 
Textoris, D.A., Robbins, E.I., and Gore, P.J.W., 1989, Origin of organic-rich strata in an upper Triassic rift basin lake, eastern USA, $28^{\text {th }}$ International Geological Congress, Washington, D. C., USA abstracts, v. 3, p.229-230.

Thayer, P.A., 1967, Geology of the Dan River and Davie County Triassic basins, North Carolina, unpublished dissertation: University of North Carolina, Chapel Hill, 195p.

Thayer, P.A., 1970, Stratigraphy and geology of Dan River Triassic basin, North Carolina: Southeastern Geology, v. 12, p. 1-31.

Tissot, B.P., and Welte, D.H., 1978, Petroleum formation and occurrence, second revised and enlarged edition: Springer-Verlag, New York, 699p.

Toenges, A.L., Turnbull, L.A., Shields, J.J., and Haley, W.A., 1952, Investigations of field and estimated reserves of coal; in coal deposits in the Deep River field, Chatham, Lee, and Moore Counties, N. C: U. S. Bureau of Mines, Bulletin 515, part 1., p. 1-10.

Vilbrandt, F.C., 1927, Oil-bearing shales of the Deep River valley: North Carolina Department of Conservation and Development, Economic Paper 59, 23p.

Waples, D., 1980, Time and temperature in petroleum formation: Application of Lopatin's method to petroleum exploration: Bulletin of the American Association of Petroleum Geologists, v. 64, No. 6., p. 916-926.

\section{Appendix A}

Organic geochemistry database of potential source rocks in Triassic strata, North Carolina Mesozoic basins. 